\title{
A description of Tussock Creek Farm
}

JOHN and JILL CLARK

Tussock Creek, RD1, Winton twojacs@xtra.co.nz

Keywords: deer farming, pasture, pasture renewal, seed mixes, sheep farming, soil fertility

\section{History and description}

John has been farming for a total of 37 years and is third generation on the family farm. Previously, 223 ha used to provide work for up to three labour units but now the farm is 65 ha smaller and John and Jill run the property by themselves. This is very much a partnership in the true sense of the word with equal responsibilities and a good working relationship.

Table 1 Area and stock numbers on Tussock Creek farm over the last 4 years.

\begin{tabular}{lcccc}
\hline & $1997 / 98$ & $1998 / 99$ & $1999 / 00$ & $2000 / 01$ \\
\hline Area (ha) & 158 & 158 & 158 & 158 \\
MA ewes & 1550 & 1550 & 1430 & 1470 \\
Ewe hoggets & 500 & 450 & 450 & 450 \\
Rams & 20 & 20 & 20 & 20 \\
MA hinds & 95 & 100 & 100 & 107 \\
Weaner stags & 3 & & & 38 \\
Weaner hinds & 27 & 45 & 45 & 44 \\
MA stags & 4 & 4 & 4 & 4 \\
Total stock units & 2286 & 2330 & 2110 & 2220 \\
Stocking rate & 14.29 & 14.56 & 13.19 & 13.88 \\
S-D ratio & & & & \\
\hline
\end{tabular}

\section{Production}

Lambing has been averaging $140-150 \%$ for more than the last 10 years. We have never exceeded $150 \%$ but to do so is definitely our current goal. Fawning percentage is running at an average of $90 \%$ or better.

\begin{tabular}{lccc}
\hline Production Season & $1997 / 98$ & $1998 / 99$ & $1999 / 00$ \\
\hline Lambing date & $10-09-97$ & $11-09-98$ & $11-09-99$ \\
Weaning date & $30-11-97$ & $14-12-98$ & $11-01-00$ \\
Weaning weight $(\mathrm{kg})$ & 25 & 27.7 & 35.5 \\
Avg. days birth to kill & 180 & 165 & 163 \\
Avg. kill date & $21-03-98$ & $07-03-99$ & $04-03-99$ \\
Avg. growth rate from birth (g/d) & 180 & 212 & 218 \\
Pre-weaning growth rate (g/d) & 286 & 289 & 304 \\
Estimated post-weaning growth & & & \\
$\quad$ rate (g/d) & 102 & 136 & 77 \\
Avg. carcass weight (kg) & 15.26 & 16.43 & 16.62 \\
kg lamb meat/ssu & 14.2 & 15.29 & 17.79 \\
kg lamb meat/sha & 201 & 214 & 233 \\
Lamb growth index & 1.39 & 1.62 & 1.77 \\
\hline
\end{tabular}

\section{Soil and management}

Soil types are mostly Pukemutu. There is a small area of Dacre Gley.

\begin{tabular}{ccccccc}
\hline $\mathrm{pH}$ & $\mathrm{P}$ & $\mathrm{Ca}$ & $\mathrm{Mg}$ & $\mathrm{Na}$ & $\mathrm{S}$ & $\mathrm{K}$ \\
$6-6.2$ & $20-25$ & $10+$ & 25 & 13 & 12 & 6 \\
\hline
\end{tabular}

- We test soil every 2 years or so.

- The historical fertiliser history is based around $2.5 \mathrm{t} /$ ha of lime every $4^{\text {th }}$ year with $250 \mathrm{~kg} / \mathrm{ha}$ of straight 0-9-0 super. Our current plan is to move towards $500 \mathrm{~kg} / \mathrm{ha}$ of lime annually with $250+\mathrm{kg} / \mathrm{ha}$ of serpentine super.

- We have started to trial some liquid fertilisers in combination with the above solids.

- Selenium prills are applied annually and cobalt as necessary via pasture spraying.

- We have moved into selective aerating and, in conjunction with our liquid, lime and solids policy, this has significantly improved soil health.

\section{Pastures}

History

- Traditionally, we used swedes and cereal cropping (1970s) but then moved into all-grass wintering until mid to late 1980s when we returned to growing swedes. The movement out of all cropping (forage and cereal) introduced another problem ... endophyte.

- The movement back to swedes was brought about by a combination of pastures starting to run out, soils seemed to be getting compaction problems, and endophyte toxins hitting hard.

- Currently, we put in up to 15 ha of swedes annually - this represents $\sim 7.5 \%$ of total area.

- We have also increased the turnover into new grass by doing some grass-to-grass renovation.

- Our goal is to have the whole farm in nil-endophyte perennial ryegrass in 5 years time.

Seed mixes

- Endophyte came in via Ellet ryegrass - this was typically sown with Huia at about $25 \mathrm{~kg} / \mathrm{ha}$. This 
type of mix was replaced by the newer cultivars when the regrassing started again in the late 1980s. Cultivars typically used were: Greenstone/Red Clover/Huia/Tahora/Timothy/Cocksfoot/Nilendophyte ryegrass.

- The current mixture now incorporate the following cultivars:

Demand/Pawera/Colseno/G27/Impact/Marsden/ Aries.

- Seeding rates were up to $28-30 \mathrm{~kg} / \mathrm{ha}$ but are now down to $20 \mathrm{~kg} / \mathrm{ha}$ total seed mix.

- Also, we like to add in forage herbs such as chicory and plantain for short-term lamb-finishing benefits.

- Regrassing is undertaken early, i.e., sowing is done by mid November.

\section{Deer unit}

\section{History}

- We got into deer in March 1987 with 8 ha. We now have 30 ha fenced and intend to fence another 10 ha next winter to give us a 40-ha unit.

- Our plan is to carry around 1.2 hinds per ha (3 per acre) (16-17su equiv/ha).

- Fourteen ha of pasture are old with some resident endophyte which will be dealt with as soon as possible.

- Our policy is to carry and finish own stock which is a movement away from selling all weaners.

- We want to keep with our breeding hinds and finishing all stags and non-replacement hinds.

- We are running all red base genetics, breeding own replacements but are considering a terminal policy and may buy in replacement red weaners.

\section{Some questions for discussion}

The following are some statements/questions we believe are current issues within this farm which may also be real issues, not only the wider Southland region, but also across New Zealand. They are intended to act as stimuli for comment and debate.

\section{Sheep genetics}

Sheep genetics have traditionally been Romney but we believed the improvement rate started to stall we had to work harder for same or less production. We decided to cross breed and have started using TefRom (Romney, Texel, East Freisian composite). Is this the way to go?

\section{Soil type}

Very wet in winter - it's hard to deal with it. Earlier comment from a scientist was, "We are getting the production that we were, not because of but in spite of the soil type". We are looking at aerating the soil. Is this "ambulance at the bottom of the cliff type" policy the way to go?

\section{Pasture mixes}

Deer need a good productive pasture for a combination of uses as traditionally, we have had to both winter and finish stock. What is the best pasture mix for Southland deer farms such as this? The herbs are very well-liked but what is the progress on breeding for persistence as they don't last or are grazed out.

\section{Pasture longevity}

What is the expected longevity of new pastures? We are seeing reversion back to old grasses even after 4-5 years - is this inevitable with our policy? What can we do to prevent it? What is a feasible prospect for our sheep and deer farm as we are not rotationally grazing as dairy farmers do?

5. Trace element supply

Copper deficiency in the deer is a serious issue and we are currently looking at spraying on copper, along with other trace elements. What is the considered opinion and likely uptake issues with sprayed-on trace elements? 